\title{
Synthesis, Characterization, and Anticancer Activity of New Benzofuran Substituted Chalcones
}

\author{
Demet Coşkun, ${ }^{1}$ Suat Tekin, ${ }^{2}$ Süleyman Sandal, ${ }^{2}$ and Mehmet Fatih Coşkun ${ }^{1}$ \\ ${ }^{1}$ Department of Chemistry, Faculty of Science, Firat University, 23119 Elazı̆g, Turkey \\ ${ }^{2}$ Department of Physiology, Faculty of Medicine, Inonu University, 44000 Malatya, Turkey
}

Correspondence should be addressed to Demet Coşkun; dcoskun@firat.edu.tr

Received 6 April 2016; Revised 26 April 2016; Accepted 8 May 2016

Academic Editor: Grigoris Zoidis

Copyright (C) 2016 Demet Coşkun et al. This is an open access article distributed under the Creative Commons Attribution License, which permits unrestricted use, distribution, and reproduction in any medium, provided the original work is properly cited.

Benzofuran derivatives are of great interest in medicinal chemistry and have drawn considerable attention due to their diverse pharmacological profiles including anticancer activity. Similarly, chalcones, which are common substructures of numerous natural products belonging to the flavonoid class, feature strong anticancer properties. A novel series of chalcones, 3-aryl-1-(5-bromo-1benzofuran-2-yl)-2-propanones propenones (3a-f), were designed, synthesized, and characterized. In vitro antitumor activities of the newly synthesized (3a-f) and previously synthesized $(\mathbf{3} \mathbf{g}-\mathbf{j})$ chalcone compounds were determined by using human breast (MCF-7) and prostate (PC-3) cancer cell lines. Antitumor properties of all compounds were determined by 3-(4,5-dimethylthiazol2-yl)-2,5-diphenyltetrazolium bromide (MTT) assay. Cell viability assay for the tested chalcone compounds was performed and the $\log \mathrm{IC}_{50}$ values of the compounds were calculated after 24-hour treatment. Our results indicate that the tested chalcone compounds show antitumor activity against MCF-7 and PC-3 cell lines $(p<0.05)$.

\section{Introduction}

Cancer is one of the most important clinical problems worldwide. Among the wide range of compounds approved as potential anticancer agents, derivatives with functionalities as $\alpha, \beta$-unsaturated Michael acceptor have attracted great interest $[1,2]$. Previous studies have proposed that anticancer compounds such as alkylating agents bind directly to various cellular nucleophiles, thus lacking selectivity. However, Michael acceptors can be structurally modified so that they can react selectively with target nucleophiles [3]. Chalcones, the compounds having 1,3-diaryl-2-propen1-one system, also have shown a broad spectrum of biological activities including anti-inflammatory [4-7], antimalarial [8], anti-invasive [9], antibacterial [10-12], and anticancer [1316] activities. On the other hand, chalcones are capable of inducing apoptosis $[17,18]$. Consequently, these compounds are recognized as promising anticancer agents [19-22]. A number of clinically useful anticancer drugs have genotoxic effects because of their interaction with the amino groups of nucleic acids. However, chalcones have been found not to show such undesired side effects [23]. Numerous reports have been published on the interesting anti-breast cancer activity shown by chalcones [24-26]. Benzofuran derivatives are an interesting class of heterocyclic compounds. Benzofuran derivatives are of great interest in medicinal chemistry and have drawn remarkable attention due to their biological activities with chemotherapeutic properties [27]. Some benzofurans bearing various substituents at the C2 position are greatly distributed in nature; for example, ailanthoidol, a neolignan derivative, has been reported to have antiviral, antioxidant, and antifungal activities [28]. Furthermore, most of the compounds prepared from 2acetylbenzofuran have antimicrobial, anticancer, antitumor, anti-inflammatory, and antitubulin activities and are also used for treatment of cardiac arrhythmias [29-32]. The use of the combinations of different pharmacological compounds in the design of new drugs may lead to finding novel drugs with interesting biological activity [33, 34]. Furthermore, no studies were found in the literature evaluating anticancer properties of benzofuran substituted chalcone derivatives. This encouraged us to synthesize benzofuran substituted chalcone compounds and to investigate anticancer properties of these compounds. 

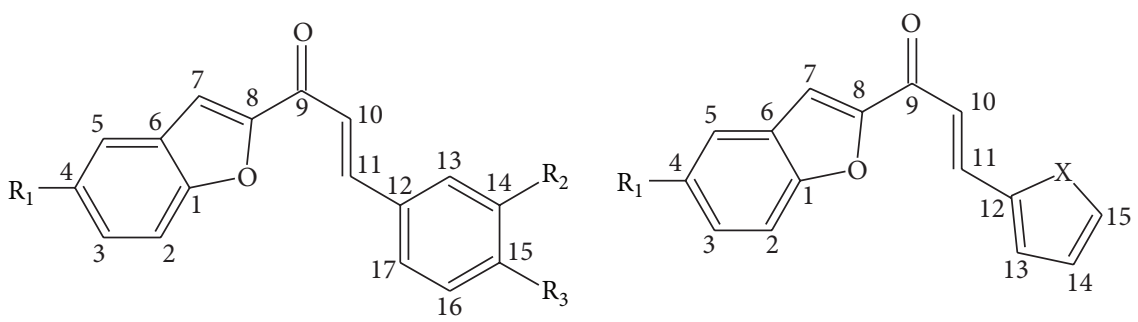

$$
\begin{aligned}
& \text { 3a: } \mathrm{R}_{1}=\mathrm{Br}, \mathrm{R}_{2}=H, \mathrm{R}_{3}=H \\
& \text { 3b: } \mathrm{R}_{1}=\mathrm{Br}, \mathrm{R}_{2}=H, \mathrm{R}_{3}=\mathrm{Br} \\
& \text { 3c: } \mathrm{R}_{1}=\mathrm{Br}, \mathrm{R}_{2}=\mathrm{NO}_{2}, \mathrm{R}_{3}=H \\
& \text { 3d: } \mathrm{R}_{1}=\mathrm{Br}, \mathrm{R}_{2}=\mathrm{H}, \mathrm{R}_{3}=\mathrm{N}\left(\mathrm{CH}_{3}\right)_{2} \\
& \text { 3i: } \mathrm{R}_{1}=\mathrm{H}, \mathrm{R}_{2}=H, \mathrm{R}_{3}=H \\
& \text { 3j: } \mathrm{R}_{1}=H, \mathrm{R}_{2}=H, \mathrm{R}_{3}=\mathrm{N}\left(\mathrm{CH}_{3}\right)_{2}
\end{aligned}
$$

$$
\begin{aligned}
& \text { 3e: } R_{1}=B r, X=O \\
& \text { 3f: } R_{1}=B r, X=S \\
& \text { 3g: } R_{1}=H, X=O \\
& \text { 3h: } R_{1}=H, X=S
\end{aligned}
$$

Scheme 1: Structure of synthetic derivatives $\mathbf{3 a} \mathbf{a} \mathbf{3} \mathbf{j}$.

In this study, we aimed at designing and synthesizing new compounds ( $\mathbf{3 a}-\mathbf{f})$ with both benzofuran and chalcone units in one molecule and examining anticancer activity of this newly synthesized chalcones (3a-f) and previously synthesized chalcones [35] (3g-j) bearing no substituent in the benzofuran ring as a different series against human breast cancer cell lines (MCF-7) and human prostate cancer cells (PC-3) (Scheme 1).

\section{Materials and Methods}

2.1. Materials. Chemical agents used in the present study included dimethyl sulfoxide (DMSO; Merck, Germany), penicillin-streptomycin, fetal bovine serum (FBS), and DMEM (Dulbecco's Modified Eagle Medium). Doubledistilled water was used at all stages of the experiments. Samples of chalcone compounds for testing were prepared at $1,5,25,50$, and $100 \mu \mathrm{M}$ concentrations.

2.2. Characterization Techniques. Melting points were measured using a differential scanning calorimeter (Shimadzu DSC-50) and were uncorrected. NMR spectra were determined on a Bruker AC $400(400 \mathrm{MHz})$ spectrometer, with tetramethylsilane (TMS) as the internal standard in DMSO$\mathrm{d}_{6}$ or $\mathrm{CDCl}_{3}$ as solvents. FT-Infrared (FT-IR) spectra were recorded as KBr pellets on a Perkin-Elmer Spectrum One FTIR spectrometer.

Synthesis of 1-(5-Bromo-1-benzofuran-2-yl)ethanone (D1). A mixture of 4-bromo salicylaldehyde $(1 \mathrm{~g}, 4.97 \mathrm{mmol})$ and potassium carbonate $(0.69 \mathrm{~g}, 4.97 \mathrm{mmol})$ in dry acetone $(10 \mathrm{~mL})$ was stirred at $25^{\circ} \mathrm{C}$ for $1 \mathrm{~h}$. Reaction mixture was cooled at $0-5^{\circ} \mathrm{C}$, and then chloroacetone $(4 \mathrm{~mL}, 4.97 \mathrm{mmol})$ was added dropwise. Reaction mixture was stirred at room temperature for ten minutes and then refluxed. Progress of the reaction was monitored by TLC. Upon completion, the reaction mixture was poured on crashed ice. The precipitated solid was filtered, washed with water, and dried. The product was crystallized from ethanol (yield $1.08 \mathrm{gr}, 91 \%$; mp: 117$\left.119^{\circ} \mathrm{C}\right)$.

FT-IR $\left(\mathrm{KBr}, \mathrm{cm}^{-1}\right) .1667(\mathrm{C}=\mathrm{O}), 1542(\mathrm{C}=\mathrm{C}) ;{ }^{1} \mathrm{H}-\mathrm{NMR}$ $\left(400 \mathrm{MHz}, \mathrm{DMSO}_{6} \mathrm{~d}_{6}\right)$, ppm: $8.03(\mathrm{~s}, 1 \mathrm{H}, 5-\mathrm{H}), 7.82(\mathrm{~s}, 1 \mathrm{H}, 7-$ $\mathrm{H}), 7.69(\mathrm{dd}, 1 \mathrm{H}, J=8.6 \mathrm{~Hz}$ and $J=8.2 \mathrm{~Hz}, 3-\mathrm{H}), 7.65(\mathrm{~d}$, $1 \mathrm{H}, J=8.8 \mathrm{~Hz}, 2-\mathrm{H}), 2.56$ (s, 3H, methyl protons); ${ }^{13} \mathrm{C}-\mathrm{NMR}$ $\left(400 \mathrm{MHz}, \mathrm{DMSO}-\mathrm{d}_{6}\right): 188.40,154.14,153.46,131.43,129.46$, 126.39, 116.63, 114.84, 113.83, 26.97; Anal. Calc.; \% C, 50.24; H, 2.95. Found: \% C, 50.21; H, 2.99 .

General Procedure for Synthesis of Chalcones (3a-f). A solution of 1-(5-bromo-1-benzofuran-2-yl)ethanone (1 g, $4.18 \mathrm{mmol})$ and one of the aldehyde derivatives ( $2 \mathbf{a}-\mathbf{f}$, $4.18 \mathrm{mmol})$ in $\mathrm{MeOH}(10 \mathrm{~mL})$ was cooled at $0-5^{\circ} \mathrm{C}$ and then $6 \mathrm{~mL}$ of aqueous $\mathrm{NaOH}(1 \mathrm{~mol} / \mathrm{L})$ was added to this solution and stirred at room temperature for $3 \mathrm{~h}$. The reaction mixture was poured on crushed ice. The precipitated solid was filtered after neutralization with diluted $\mathrm{HCl}$ and was washed several times with water and then dried. The product was recrystallized from ethanol.

(2E)-1-(5-Bromo-1-benzofuran-2-yl)-3-phenylprop-2-en-1-one (3a). Yield: 70\%; M.p. $145-147^{\circ} \mathrm{C}$; FT-IR $\left(\mathrm{KBr}, \mathrm{cm}^{-1}\right): 1655$ $(\mathrm{C}=\mathrm{O}), 1599(\mathrm{C}=\mathrm{C}) ;{ }^{1} \mathrm{H}-\mathrm{NMR}\left(400 \mathrm{MHz}, \mathrm{DMSO}^{-} \mathrm{d}_{6}\right)$, ppm: 8.27 (s, 1H, 5-H), $8.12(\mathrm{~s}, 1 \mathrm{H}, 7-\mathrm{H}), 7.92-7.84(\mathrm{~m}, 4 \mathrm{H}, 13-\mathrm{H}$, 17-H, 10-H, 11-H), 7.84-7.65 (m, 2H, 3-H, 2-H), 7.65-7.40 (m, $3 \mathrm{H}, 16-\mathrm{H}, 15-\mathrm{H}, 14-\mathrm{H}) ;{ }^{13} \mathrm{C}-\mathrm{NMR}\left(400 \mathrm{MHz}, \mathrm{DMSO}_{6} \mathrm{~d}_{6}\right.$ : $178.96,154.59,154.55,144.46,134.76,131.63,131.46,129.64$, $129.50,129.46,126.49,122.18,116.77,114.88$, 114.56; Anal. Calc.; \% C, 62.41; H, 3.39 Found: \% C, 62.43; H, 3.43.

(2E)-1-(5-Bromo-1-benzofuran-2-yl)-3-(3-bromophenyl)prop2-en-1-one (3b). Yield: 82\%; M.p. 206-208 ${ }^{\circ} \mathrm{C}$; FT-IR (KBr, $\left.\mathrm{cm}^{-1}\right): 1654(\mathrm{C}=\mathrm{O}), 1604(\mathrm{C}=\mathrm{C}) ;{ }^{1} \mathrm{H}-\mathrm{NMR} \quad(400 \mathrm{MHz}$, DMSO- $\left.\mathrm{d}_{6}\right)$, ppm: $8.29(\mathrm{~s}, 1 \mathrm{H}, 5-\mathrm{H}), 8.15(\mathrm{~s}, 1 \mathrm{H}, 7-\mathrm{H}), 8.00-$ $7.62(\mathrm{~m}, 8 \mathrm{H}, 3-\mathrm{H}, 2-\mathrm{H}, 17-\mathrm{H}, 16-\mathrm{H}, 14-\mathrm{H}, 13-\mathrm{H}, 10-\mathrm{H}, 11-\mathrm{H})$; ${ }^{13}$ C-NMR (400 MHz，DMSO-d $\left.)_{6}\right): 178.90,154.58,154.52$, $143.18,134.04,132.47,131.78,131.68,131.43,129.62,126.59$, 
124.98, 122.87, 116.84, 114.98; Anal. Calc.; \% C, 50.28; H, 2.48 Found: \% C, 50.24; H, 2.50 .

(2E)-1-(5-Bromo-1-benzofuran-2-yl)-3-(3-nitrophenyl)prop2-en-1-one (3c). Yield: 87\%; M.p. 202-204 C; FT-IR (KBr, $\left.\mathrm{cm}^{-1}\right)$ : $1666(\mathrm{C}=\mathrm{O}), 1610 \quad(\mathrm{C}=\mathrm{C}) ;{ }^{1} \mathrm{H}-\mathrm{NMR} \quad(400 \mathrm{MHz}$, DMSO-d ${ }_{6}$ ), ppm: 8.78 (s, 1H, 5-H), 8.37-8.27 (m, 13-H, 15-H, 17-H), 8.13 (s, 1H, 7-H), 8.08 (d, 1H, $J=15.6 \mathrm{~Hz}, 11-\mathrm{H}), 7.92$ (d, $1 \mathrm{H}, J=16 \mathrm{~Hz}, 10-\mathrm{H}), 7.78-7.68(\mathrm{~m}, 3 \mathrm{H}, 3-\mathrm{H}, 2-\mathrm{H}, 16-\mathrm{H})$; ${ }^{13} \mathrm{C}-\mathrm{NMR}\left(400 \mathrm{MHz}, \mathrm{DMSO}-\mathrm{d}_{6}\right)$ : 178.73, 154.67, 154.40, $148.95,141.86,136.66,135.70,131.87,130.92,129.57,126.59$, 125.43, 124.88, 123.51, 116.85, 115.39, 114.93; Anal. Calc.; \% C, 54.86; H, 2.71; N, 3.76 Found: \% C, 54.90; H, 2.76; N, 3.75.

(2E)-1-(5-Bromo-1-benzofuran-2-yl)-3-[4-(dimethylamino)phenyl]prop-2-en-1-one (3d). Yield: 70\%; M.p. $179-181^{\circ} \mathrm{C}$; FT-IR $\left(\mathrm{KBr}, \mathrm{cm}^{-1}\right)$ : $1646(\mathrm{C}=\mathrm{O}), 1579(\mathrm{C}=\mathrm{C}) ;{ }^{1} \mathrm{H}-\mathrm{NMR}$ (400 MHz, DMSO-d 6 ), ppm: 8.10 (s, 2H, 5-H, 7-H), 7.78-7.56 (m, 6H, 3-H, 2-H, 13-H, 17-H, 10-H, 11-H), 6.77 (d, 1H, $J=2.8 \mathrm{~Hz}, 14-\mathrm{H}), 6.75(\mathrm{~d}, 1 \mathrm{H}, J=3.6 \mathrm{~Hz}, 16-\mathrm{H}), 3.02(\mathrm{~s}$, $\left.6 \mathrm{H}, \mathrm{CH}_{3}\right) ;{ }^{13} \mathrm{C}-\mathrm{NMR}\left(400 \mathrm{MHz}, \mathrm{DMSO}-\mathrm{d}_{6}\right): 178.52,155.35$, $154.31,152.75,145.69,131.61,131.10,129.85,126.24,122.00$, $116.64,115.98,114.83,112.98,112.22$, 40.56-39.31; Anal. Calc.; \% C, 61.64; H, 4.36; N, 3.78 Found: \% C, 61.40; H, 3.31; N, 3.80 .

(2E)-1-(5-Bromo-1-benzofuran-2-yl)-3-(2-furyl)prop-2-en-1one (3e). Yield: $83 \%$; M.p. $170-172^{\circ} \mathrm{C}$; FT-IR $\left(\mathrm{KBr}, \mathrm{cm}^{-1}\right)$ : 1658 $(\mathrm{C}=\mathrm{O}), 1596(\mathrm{C}=\mathrm{C}) ;{ }^{1} \mathrm{H}-\mathrm{NMR}\left(400 \mathrm{MHz}, \mathrm{DMSO}-\mathrm{d}_{6}\right)$, ppm: 8.03-7.96 (m, 3H, 5-H, 7-H, 15-H), 7.74-7.62 (m, 3H, 3-H, 2-H, 11-H), 7.55-7.40 (d, 1H, J = 15.2 Hz, 10-H), 7.14 (s, 1H, 13-H), 6.71 (s, 1H, 14-H); ${ }^{13} \mathrm{C}-\mathrm{NMR}\left(400 \mathrm{MHz}, \mathrm{DMSO}-\mathrm{d}_{6}\right)$ : $178.56,154.54,154.41,151.34,147.15,131.48,130.78,129.65$, 126.37, 118.73, 118.50, 116.72, 114.85, 114.57, 113.77; Anal. Calc.; \% C, 56.81; H, 2.86 Found: \% C, 56.75; H, 2.90.

(2E)-1-(5-Bromo-1-benzofuran-2-yl)-3-(2-thienyl)prop-2-en1-one (3f). Yield: $83 \%$; M.p. $168-170^{\circ} \mathrm{C}$; FT-IR $\left(\mathrm{KBr}, \mathrm{cm}^{-1}\right)$ : $1660(\mathrm{C}=\mathrm{O}), 1602(\mathrm{C}=\mathrm{C}) ;{ }^{1} \mathrm{H}-\mathrm{NMR}\left(400 \mathrm{MHz}, \mathrm{DMSO}-\mathrm{d}_{6}\right)$, ppm: 8.17 (s, 1H, 5-H), 8.09 (s, 1H, 7-H), 8.02 (d, 1H, $J=15.6$, 11-H), 7.91-7.67 (m, 4H, 3-H, 2-H, 15-H and 13-H), 7.51 (d, $1 \mathrm{H}$, $J=15.2 \mathrm{~Hz}, 10-\mathrm{H}), 7.23(\mathrm{dd}, 1 \mathrm{H}, 14-\mathrm{H}) ;{ }^{13} \mathrm{C}-\mathrm{NMR}(400 \mathrm{MHz}$, DMSO- $\left.\mathrm{d}_{6}\right): 178.54,154.53,154.48,139.86,137.27,134.10$, $131.64,131.54,129.69,129.36,126.42,120.35,116.76,114.90$, 114.05; Anal. Calc.; \% C, 56.81; H, 2.86 Found: \% C, 56.75; H, 2.90 .

\subsection{In Vitro Antitumor Activity}

2.3.1. Cell Culture. The cell lines of human breast cancer (MCF-7) and human prostate cancer (PC-3) were employed in our study. The PC-3 and MCF-7 cell lines were retrieved from American Type Culture Collection (ATCC). MCF-7 and PC-3 cells were fed with DMEM medium (supplemented with $4500 \mathrm{mg} / \mathrm{L}$ glucose, $10 \% \mathrm{FBS}, 100 \mathrm{U} / \mathrm{mL}$ penicillin, and $0.1 \mathrm{mg} / \mathrm{mL}$ streptomycin added) in $75 \mathrm{~cm}^{2}$ culture flasks and RPMI-1640 medium (supplemented 10\% FBS, $100 \mathrm{U} / \mathrm{mL}$ penicillin, and $0.1 \mathrm{mg} / \mathrm{mL}$ streptomycin added), respectively. A humidified carbon dioxide incubator $\left(5 \% \mathrm{CO}_{2}+95 \% \mathrm{O}_{2}\right.$;
Panasonic, Japan) was used to keep all cells at $37^{\circ} \mathrm{C}$ during the experiments. Before the treatment of chalcone compounds, the viability ratios of the cells were identified by $0.4 \%$ trypan blue. If the viability ratios were under $90 \%$, we did not initiate the experiments [36].

2.3.2. MTT Assay. The synthetic chalcone derivatives were tested for their antitumor activities against different type cancer cell lines (PC-3 and MCF-7) using 3-(4,5-dimethylthiazol-2-yl)-2,5-diphenyl tetrazolium bromide (MTT) assay method. The pale-yellow tetrazolium salt, MTT, was transformed by active mitochondria to form a dark blue formazan that was determined by a microplate reader [37]. The MTT method provides a simple way to detect living and growing cells without using radioactivity.

When the cells were confluent, they were removed from the flasks using trypsin-EDTA solution and were seeded in 96-well plates such that there were $15 \times 10^{3}$ cells in each well. The plates were incubated for $24 \mathrm{~h}$ at $37^{\circ} \mathrm{C}$. After treatment of these cancer cells with DMSO (for positive control group) and different concentrations $(1,5,25,50$, and $100 \mu \mathrm{M})$ of chalcone compounds (D1, 3a-j) in DMSO, the cells then were incubated for $24 \mathrm{~h}$ at $37^{\circ} \mathrm{C}$ in $5 \% \mathrm{CO}_{2}$ humidified incubator. MTT solution $(0.5 \mathrm{mg} / \mathrm{mL})$ was prepared from the MTT stock solution in sterile PBS and was added to each well and the plates were then incubated for $3 \mathrm{~h}$ after the incubation for $24 \mathrm{~h}$ with chalcone compounds. After that, DMSO and the optical density of the cells were determined by an ELISA reader (Synergy HT, USA) at $550 \mathrm{~nm}$ wavelength. The averages of the absorbance values were recorded by reading the control wells that were considered as $100 \%$. The values of absorbance achieved from chalcone compounds and solvent (DMSO) added wells were proportioned to the control values, and the percentages of cell viability were determined. The tests were reiterated ten times at several days [38].

2.4. Statistical Analyses. Quantitative data are expressed as mean \pm standard deviation (SD). Normal distribution was confirmed using Kolmogorov-Smirnov test. Quantitative data were analyzed using Kruskal-Wallis $H$ test following Mann-Whitney $U$ test with Bonferroni adjustment as a post hoc test. All $p$ values < 0.05 were considered as statistically significant. All analyses were done by IBM SPSS Statistics 22.0 for Windows. The $\log \mathrm{IC}_{50}$ values were determined by using $\%$ cell viability values of compounds by GraphPad Prism 6 program.

\section{Results and Discussion}

The new 1-(5-bromo-1-benzofuran-2-yl)ethanone was obtained from the reaction of 5-bromosalicylaldehyde and 1chloroacetone. A series of chalcones $(\mathbf{3} \mathbf{a}-\mathbf{f})$ were synthesized by condensation of 1-(5-bromo-1-benzofuran-2-yl)ethanone and various aromatic aldehydes (2a-f) (Scheme 2). For the synthesis of chalcones, the most common route is the basecatalyzed Claisen-Schmidt reaction involving condensation 


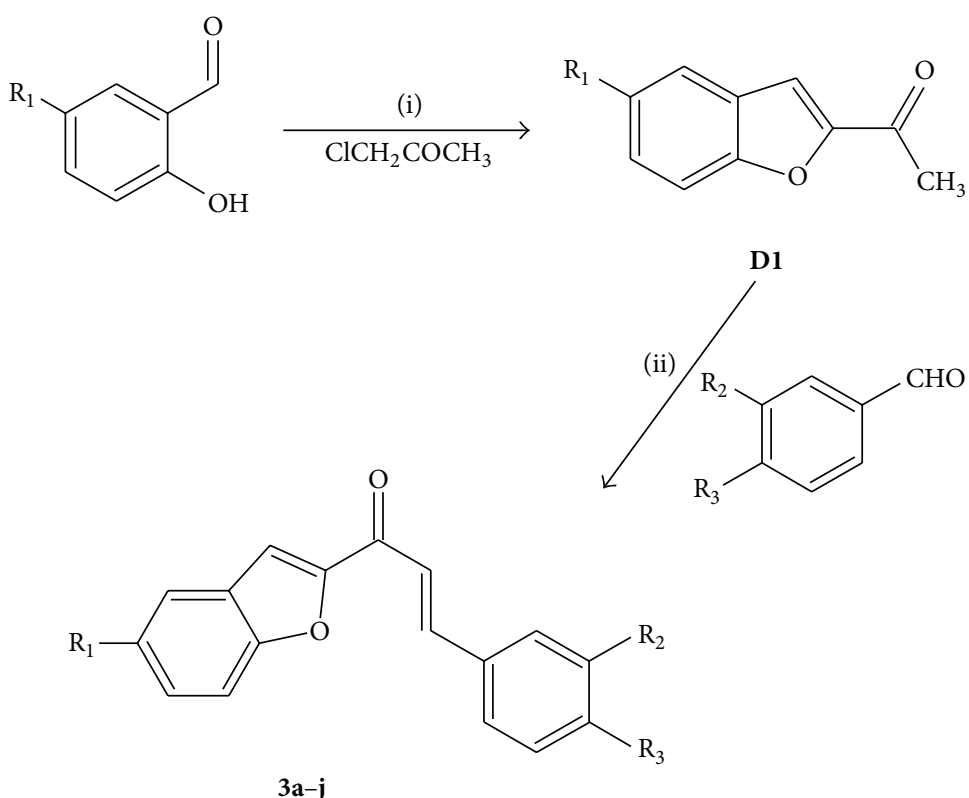

SCHEME 2: General synthesis of benzofuran ketone (D1) with chalcone derivatives (3a-j). Reagents and conditions (i). $\mathrm{K}_{2} \mathrm{CO}_{3}$, acetone, reflax; (ii). $\mathrm{NaOH}, \mathrm{MeOH}$, rt.

of a benzaldehyde derivative with an acetophenone derivative in methanol with sodium hydroxide catalyst [39-41].

The benzofuran substituted chalcone derivatives (3a-f) were characterized by elemental analysis, FT-IR, ${ }^{1} \mathrm{H}$, and ${ }^{13} \mathrm{C}$ NMR spectroscopy techniques.

Anticancer activity against MCF-7 and PC-3 was investigated in both these newly synthesized chalcones $(\mathbf{3 a}-\mathbf{f})$ and previously synthesized chalcone derivatives $(\mathbf{3} \mathbf{g}-\mathbf{j})$.

3.1. Structural Characterization. In the FT-IR spectra of 1-(5bromo-1-benzofuran-2-yl)ethanone, $\mathrm{C}=\mathrm{O}$ stretching vibration was observed at $1667 \mathrm{~cm}^{-1}$. The synthetic chalcones $3 \mathrm{a}-$ f showed characteristic bands between 1646 and $1666 \mathrm{~cm}^{-1}$ ( $\mathrm{C}=\mathrm{O}$ stretching at chalcone) and between 1579 and $1610 \mathrm{~cm}^{-1}$ $(\mathrm{C}=\mathrm{C}$ stretching at chalcone).

The most characteristic signals in ${ }^{1} \mathrm{H}-\mathrm{NMR}$ spectra of the benzofuran substituted chalcones were observed at 8.29$8.03 \mathrm{ppm}$ (B3-H at benzofuran ring) and at 7.80-7.40 ppm $(\alpha-$ $\mathrm{H}$ and $\beta-\mathrm{H}$ of chalcone moiety) with a coupling constant about $15 \mathrm{~Hz}$ which characterized the transconfiguration of the alkene moiety. The signal of $\beta-\mathrm{H}$ was found downfield at a lower field than that of $\alpha$-H due to resonance of $\pi$-electrons between $\alpha$-carbons and $\beta$-carbons with carbonyl group. The carbonyl carbon was observed at about $178 \mathrm{ppm}$ in the ${ }^{13} \mathrm{C}$ NMR spectra of $\mathbf{3 a}-\mathbf{f}$.

3.2. Anticancer Activity. The benzofuran substituted chalcone compounds synthesized were tested for their in vitro anticancer activity against two cancer cell lines including MCF-7 and PC-3 at five different concentrations (1, 5, 25, 50 , and $100 \mu \mathrm{M})$ by MTT assay. The cell viability percentages of tested benzofuran substituted chalcone compounds were
TABLE 1: Evaluation of the cytotoxicity and $\log \mathrm{IC}_{50}$ values $(\mu \mathrm{M})$ of chalcone compounds and docetaxel (reference chemotherapeutic drug) of two cancer cell lines. $\log \mathrm{IC}_{50}$ is the concentration of drug that reduces cell growth by $50 \%$.

\begin{tabular}{lcc}
\hline Compound & $\begin{array}{c}\text { MCF-7 } \\
\log \mathrm{IC}_{50}(\mu \mathrm{M})\end{array}$ & $\begin{array}{c}\text { PC-3 } \\
\log \mathrm{IC}_{50}(\mu \mathrm{M})\end{array}$ \\
\hline D1 & 2.12 & 1.54 \\
3a & 1.89 & 1.67 \\
3b & 1.45 & 1.24 \\
3c & 5.01 & 6.31 \\
3d & 5.79 & 1.81 \\
3e & 0.42 & 0.67 \\
3f & 2.30 & 2.47 \\
3g & 4.43 & 6.11 \\
3h & 2.55 & 2.57 \\
3i & 6.28 & 6.30 \\
3j & -0.21 & 0.92 \\
Docetaxel (reference drug) & -0.48 & -0.52 \\
\hline
\end{tabular}

determined. Figures 1 and 2 show the effects of the benzofuran substituted chalcones on cell viability measured at $24 \mathrm{~h}$ after exposure.

$\log \mathrm{IC}_{50}$ values of compounds $3 \mathbf{a}-\mathbf{j}$ were calculated by using inhibition percentage values by GraphPad Prism 6 program on a computer. $\log \mathrm{IC}_{50}$ results of this compound are given in Table 1.

The benzofuran substituted chalcones showed anticancer activity on PC-3 and MCF-7 cell lines $(p<0.05)$. All the compounds at $100 \mu \mathrm{M}$ concentrations significantly reduced the viability percentage of PC-3 and MCF-7 cells $(p<0.001)$. 

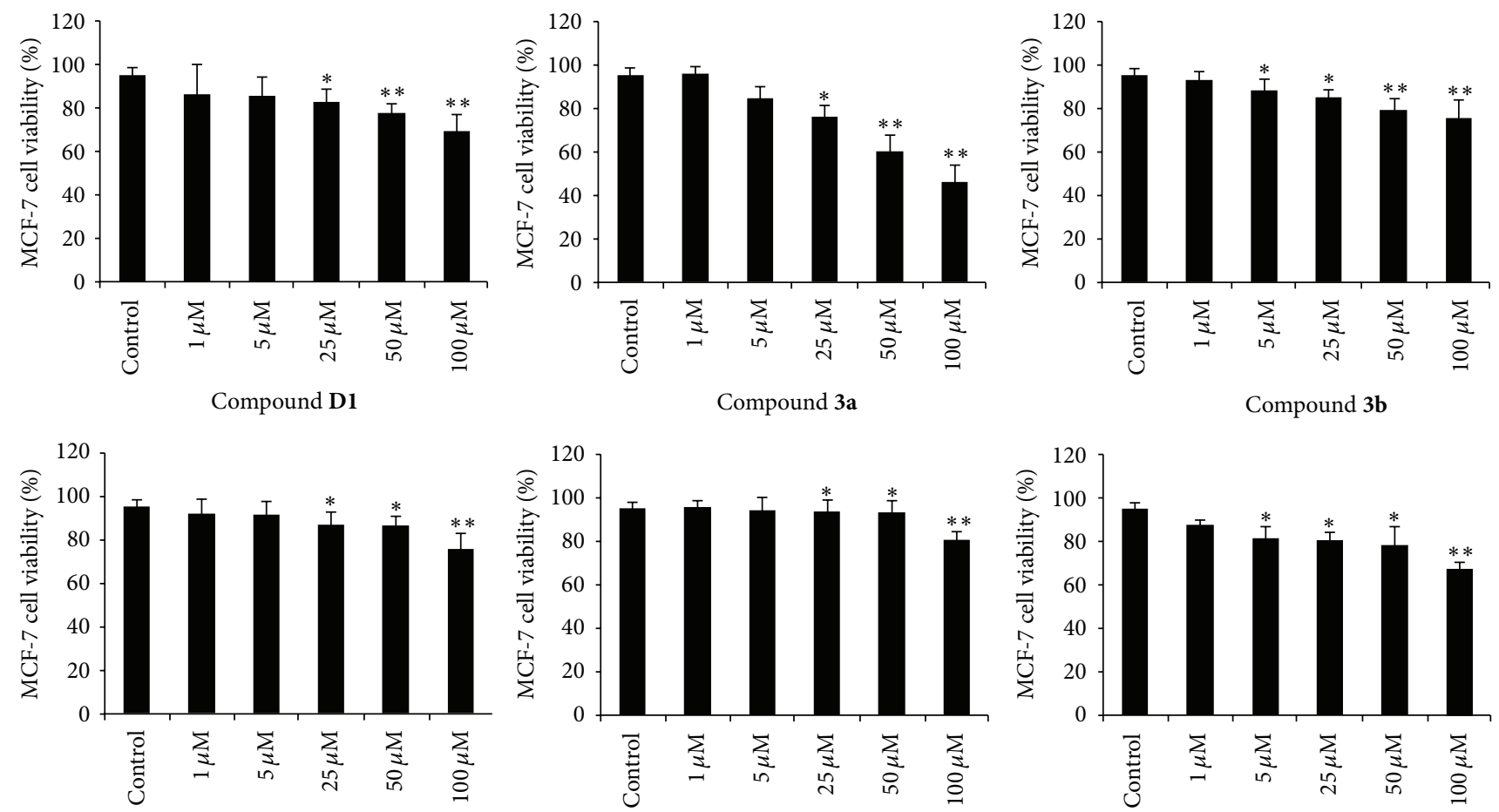

Compound 3c

Compound 3d

Compound $3 \mathrm{e}$

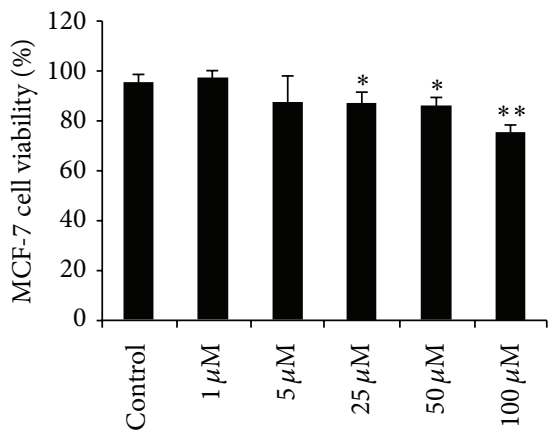

Compound $\mathbf{3 f}$

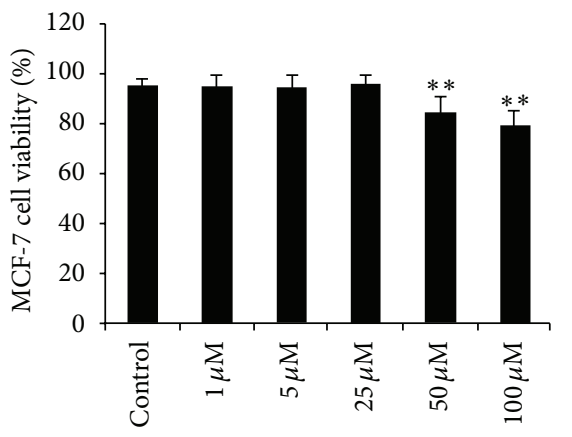

Compound 3g

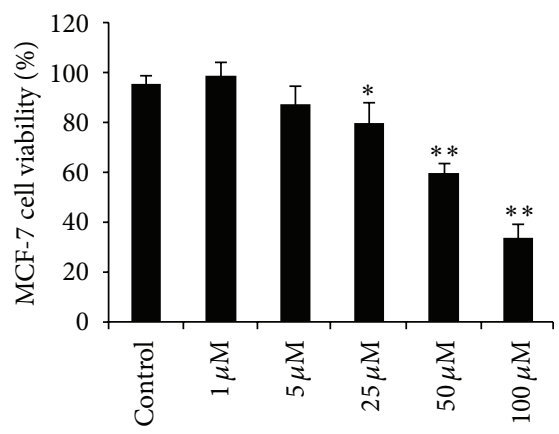

Compound $\mathbf{3 h}$

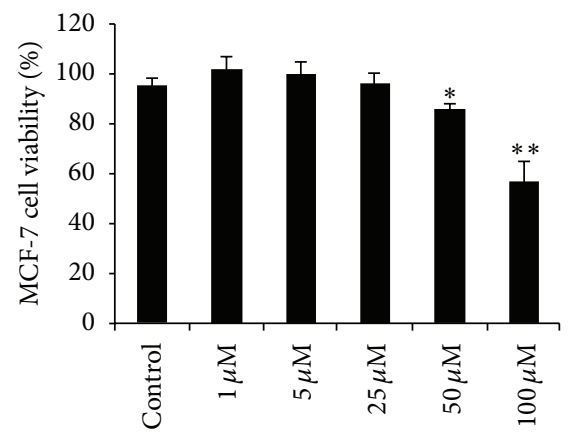

Compound $\mathbf{3 i}$

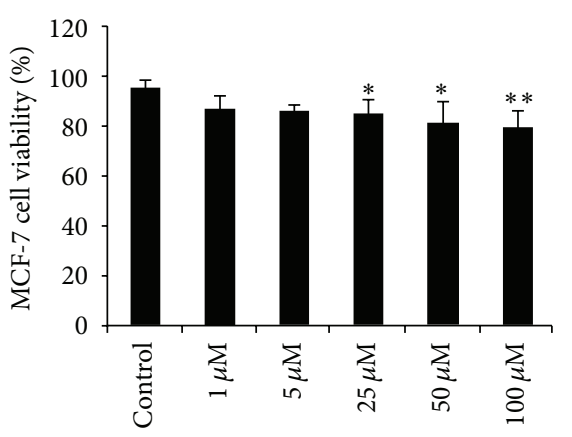

Compound $\mathbf{3 j}$

FIGURE 1: The relative cell viability (\%) of MCF-7 cells following the exposure of various concentrations of all the compounds (D1 and 3a-j) and untreated control cell for $24 \mathrm{~h}\left({ }^{*} p<0.05 ;{ }^{* *} p<0.001\right)$.

Structure activity relationships between these chalcone derivatives and starting material (D1) demonstrated that benzofuran substituted chalcones showed more potent activities than the starting material bearing only an unsubstituted benzofuran ring.
Among the synthesized chalcones, compounds 3a, 3h, and $3 \mathbf{i}$ were found to be the most potent against MCF-7 and PC-3 cell lines. In general, chalcone derivatives show anticancer activity. We have not run across any study in literature on the synthesis and anticancer properties of 

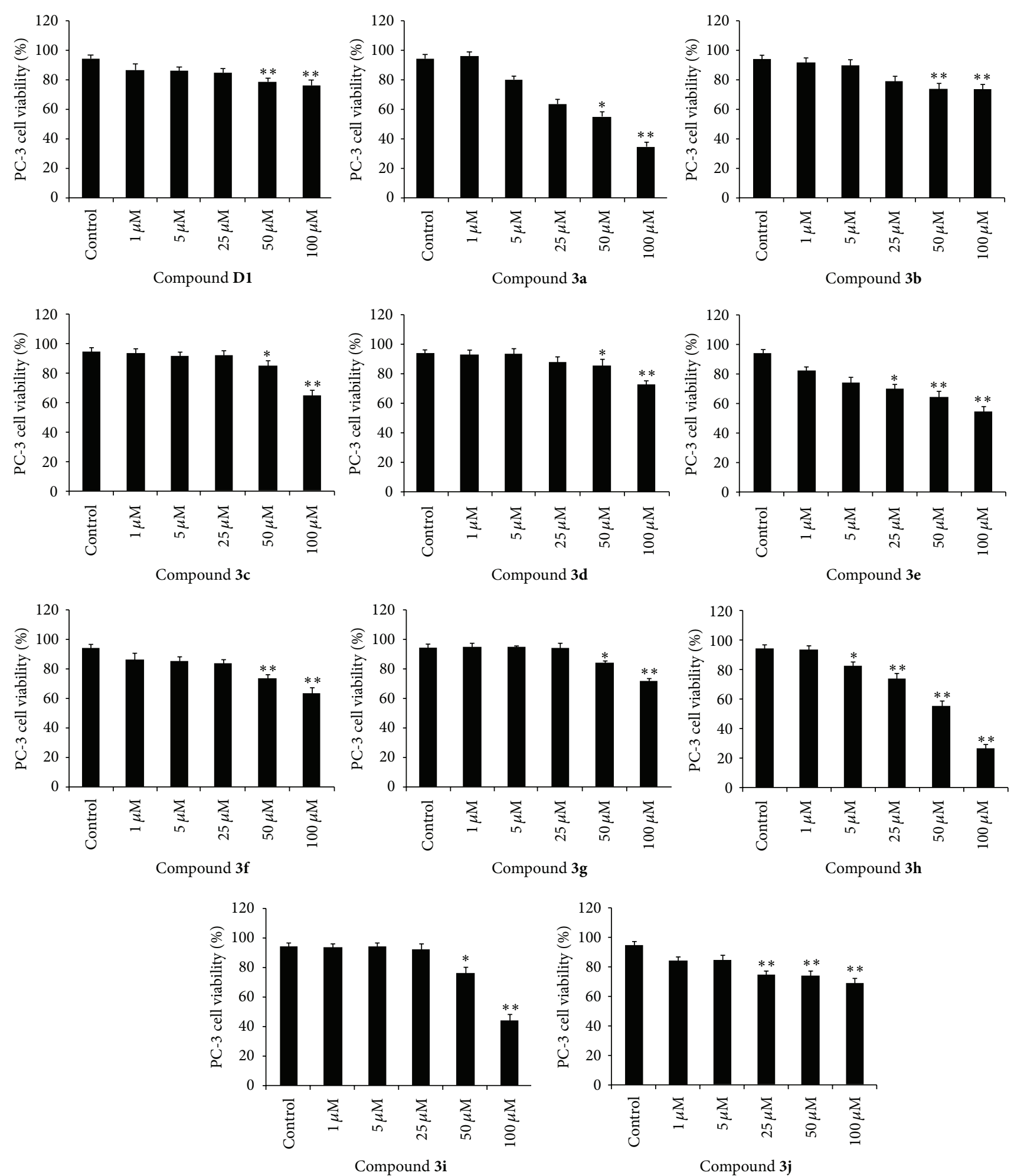

FIGURE 2: The relative cell viability (\%) of PC-3 cells following the exposure of various concentrations of all the compounds (D1 and $\mathbf{3 a - j}$ ) and untreated control cell for $24 \mathrm{~h}\left({ }^{*} p<0.05 ;{ }^{* *} p<0.001\right)$. 
the chalcone compounds containing benzofuran ring. In this study we have firstly synthesized the chalcone compounds containing benzofuran ring. And also we have firstly studied on the anticancer properties of these compounds. We have studied only MCF-7 and PC-3 cells. These results suggested that benzofuran substituted chalcones could be used as lead compounds to develop novel potent anticancer agents.

\section{Conclusions}

Synthetic benzofuran chalcone compounds were evaluated in vitro for their anticancer activity by MTT assay. The benzofuran substituted chalcone derivatives showed high antitumor activity against MCF-7 and PC-3 cell lines $(p<$ $0.001)$. These results displayed that chalcone derivatives bearing benzofuran ring may be useful in the future for anticancer drug development.

\section{Competing Interests}

The authors declare that they have no competing interests.

\section{Acknowledgments}

The authors thank Firat University for financial support of this work.

\section{References}

[1] Y.-L. Chen, S.-Z. Lin, J.-Y. Chang et al., "In vitro and in vivo studies of a novel potential anticancer agent of isochaihulactone on human lung cancer A549 cells," Biochemical Pharmacology, vol. 72, no. 3, pp. 308-319, 2006.

[2] R. Abonia, D. Insuasty, J. Castillo et al., "Synthesis of novel quinoline-2-one based chalcones of potential anti-tumor activity," European Journal of Medicinal Chemistry, vol. 57, pp. 29-40, 2012.

[3] B.-Z. Ahn and D.-E. Sok, "Michael acceptors as a tool for anticancer drug design," Current Pharmaceutical Design, vol. 2, no. 3, pp. 247-262, 1996.

[4] Z. Nowakowska, "A review of anti-infective and anti-inflammatory chalcones," European Journal of Medicinal Chemistry, vol. 42, no. 2, pp. 125-137, 2007.

[5] X.-W. Zhang, D.-H. Zhao, Y.-C. Quan, L.-P. Sun, X.-M. Yin, and L.-P. Guan, "Synthesis and evaluation of antiinflammatory activity of substituted chalcone derivatives," Medicinal Chemistry Research, vol. 19, no. 4, pp. 403-412, 2010.

[6] H. Iqbal, V. Prabhakar, A. Sangith, B. Chandrika, and R. Balasubramanian, "Synthesis, anti-inflammatory and antioxidant activity of ring-a-monosubstituted chalcone derivatives," Medicinal Chemistry Research, vol. 23, no. 10, pp. 4383-4394, 2014.

[7] M. Wan, L. Xu, L. Hua et al., "Synthesis and evaluation of novel isoxazolyl chalcones as potential anticancer agents," Bioorganic Chemistry, vol. 54, pp. 38-43, 2014.

[8] A. Agarwal, K. Srivastava, S. K. Puri, and P. M. S. Chauhan, "Antimalarial activity and synthesis of new trisubstituted pyrimidines," Bioorganic and Medicinal Chemistry Letters, vol. 15, no. 12, pp. 3130-3132, 2005.
[9] M. L. Go, X. Wu, and X. L. Liu, "Chalcones: an update on cytotoxic and chemoprotective properties," Current Medicinal Chemistry, vol. 12, no. 4, pp. 483-499, 2005.

[10] P. M. Sivakumar, S. Ganesan, P. Veluchamy, and M. Doble, "Novel chalcones and 1,3,5-triphenyl-2-pyrazoline derivatives as antibacterial agents," Chemical Biology \& Drug Design, vol. 76, no. 5, pp. 407-411, 2010.

[11] H. Adibi, J. S. Mojarrad, H. Asgharloo, and G. Zarrini, "Synthesis, in vitro antimicrobial and antioxidant activities of chalcone and flavone derivatives holding allylic substitutions," Medicinal Chemistry Research, vol. 20, no. 8, pp. 1318-1324, 2011.

[12] K. Parikh and D. Joshi, "Antibacterial and antifungal screening of newly synthesized benzimidazole-clubbed chalcone derivatives," Medicinal Chemistry Research, vol. 22, no. 8, pp. 36883697, 2013.

[13] J. C. Aponte, M. Verástegui, E. Málaga et al., "Synthesis, cytotoxicity, and anti-Trypanosoma cruzi activity of new chalcones," Journal of Medicinal Chemistry, vol. 51, no. 19, pp. 6230-6234, 2008.

[14] A. Shah, A. M. Khan, R. Qureshi, F. L. Ansari, M. F. Nazar, and S. S. Shah, "Redox behavior of anticancer chalcone on a glassy carbon electrode and evaluation of its interaction parameters with DNA," International Journal of Molecular Sciences, vol. 9, no. 8, pp. 1424-1434, 2008.

[15] J. Quintin, J. Desrivot, S. Thoret, P. L. Menez, T. Cresteil, and G. Lewin, "Synthesis and biological evaluation of a series of tangeretin-derived chalcones," Bioorganic \& Medicinal Chemistry Letters, vol. 19, no. 1, pp. 167-169, 2009.

[16] S. N. Mokale, P. N. Dube, S. A. Bhavale et al., "Synthesis, invitro screening, and docking analysis of novel pyrrolidine and piperidine-substituted ethoxy chalcone as anticancer agents," Medicinal Chemistry Research, vol. 24, no. 5, pp. 1842-1856, 2015.

[17] M. Maggiolini, G. Statti, A. Vivacqua et al., "Estrogenic and antiproliferative activities of isoliquiritigenin in MCF7 breast cancer cells," The Journal of Steroid Biochemistry and Molecular Biology, vol. 82, no. 4-5, pp. 315-322, 2002.

[18] T. Sakai, R. N. Eskander, Y. Guo et al., "Flavokawain B, a kava chalcone, induces apoptosis in synovial sarcoma cell lines," Journal of Orthopaedic Research, vol. 30, no. 7, pp. 1045-1050, 2012.

[19] S. K. Kumar, E. Hager, C. Pettit, H. Gurulingappa, N. E. Davidson, and S. R. Khan, "Design, synthesis, and evaluation of novel boronic-chalcone derivatives as antitumor agents," Journal of Medicinal Chemistry, vol. 46, no. 14, pp. 2813-2815, 2003.

[20] B. Srinivasan, T. E. Johnson, R. Lad, and C. Xing, "Structureactivity relationship studies of chalcone leading to 3-hydroxy4,3',4',5/-tetramethoxychalcone and its analogues as potent nuclear factor $\kappa \mathrm{B}$ inhibitors and their anticancer activities," Journal of Medicinal Chemistry, vol. 52, no. 22, pp. 7228-7235, 2009.

[21] D. Kumar, N. M. Kumar, K. Akamatsu, E. Kusaka, H. Harada, and T. Ito, "Synthesis and biological evaluation of indolyl chalcones as antitumor agents," Bioorganic \& Medicinal Chemistry Letters, vol. 20, no. 13, pp. 3916-3919, 2010.

[22] S.-H. Kim, E. Lee, K. H. Baek et al., "Chalcones, inhibitors for topoisomerase $\mathrm{i}$ and cathepsin $\mathrm{B}$ and $\mathrm{L}$, as potential anti-cancer agents," Bioorganic and Medicinal Chemistry Letters, vol. 23, no. 11, pp. 3320-3324, 2013.

[23] H.-J. Zhang, Y. Qian, D.-D. Zhu, X.-G. Yang, and H.-L. Zhu, "Synthesis, molecular modeling and biological evaluation of 
chalcone thiosemicarbazide derivatives as novel anticancer agents," European Journal of Medicinal Chemistry, vol. 46, no. 9, pp. 4702-4708, 2011.

[24] A. Kamal, J. S. Reddy, M. J. Ramaiah et al., "Design, synthesis and biological evaluation of imidazopyridine/pyrimidinechalcone derivatives as potential anticancer agents," Medicinal Chemical Communications, vol. 1, no. 5, pp. 355-360, 2010.

[25] A. Sharma, B. Chakravarti, M. P. Gupt, J. A. Siddiqui, R. Konwar, and R. P. Tripathi, "Synthesis and anti breast cancer activity of biphenyl based chalcones," Bioorganic and Medicinal Chemistry, vol. 18, no. 13, pp. 4711-4720, 2010.

[26] K. Juvale, V. F. S. Pape, and M. Wiese, "Investigation of chalcones and benzochalcones as inhibitors of breast cancer resistance protein," Bioorganic and Medicinal Chemistry, vol. 20, no. 1, pp. 346-355, 2012.

[27] V. Ugale, H. Patel, B. Patel, and S. Bari, "Benzofurano-isatins: search for antimicrobial agents," Arabian Journal of Chemistry, 2012.

[28] C.-L. Kao and J.-W. Chern, "A convenient synthesis of naturally occurring benzofuran ailanthoidol," Tetrahedron Letters, vol. 42, no. 6, pp. 1111-1113, 2001.

[29] R. Basawaraj, B. Yadav, and S. S. Sangapure, "Synthesis of some $1 \mathrm{H}$-pyrazolines bearing benzofuran as biologically active agents," Indian Journal of Heterocyclic Chemistry, vol. 11, no. 1, pp. 31-34, 2001.

[30] S. M. Rida, S. A. M. El-Hawash, H. T. Y. Fahmy, A. A. Hazzaa, and M. M. M. El-Meligy, "Synthesis of novel benzofuran and related benzimidazole derivatives for evaluation of in vitro anti-HIV-1, anticancer and antimicrobial activities," Archives of Pharmacal Research, vol. 29, no. 10, pp. 826-833, 2006.

[31] R. K. Ujjinamatada, R. S. Appala, and Y. S. Agasimundin, "Synthesis and antimicrobial activity of new benzofuranyl-1,3benzoxazines and 1,3-benzoxazin-2-ones," Journal of Heterocyclic Chemistry, vol. 43, no. 2, pp. 437-441, 2006.

[32] R. Romagnoli, P. G. Baraldi, T. Sarkar et al., "Synthesis and biological evaluation of 2-aroyl-4-phenyl-5-hydroxybenzofurans as a new class of antitubulin agents," Medicinal Chemistry, vol. 4, no. 6, pp. 558-564, 2008.

[33] Y. C. Mayur, G. J. Peters, V. V. S. Rajendra Prasad, C. Lemos, and N. K. Sathish, "Design of new drug molecules to be used in reversing multidrug resistance in cancer cells," Current Cancer Drug Targets, vol. 9, no. 3, pp. 298-306, 2009.

[34] V. R. Solomon, C. Hu, and H. Lee, "Hybrid pharmacophore design and synthesis of isatin-benzothiazole analogs for their anti-breast cancer activity," Bioorganic and Medicinal Chemistry, vol. 17, no. 21, pp. 7585-7592, 2009.

[35] D. Coşkun and M. Ahmedzade, “3-(Substituted aryl)-1-(benzofuran-2-yl)-2-propenones, part 1: synthesis and characterization of some novel chalcones," Synthetic Communications, vol. 38, no. 21, pp. 3613-3622, 2008.

[36] H. Küçükbay, A. Mumcu, S. Tekin, and S. Sandal, "Synthesis and evaluation of novel N,N'-disubstituted benzimidazolium bromides salts as antitumor agents," Turkish Journal of Chemistry, vol. 40, pp. 393-401, 2016.

[37] N. Kolocouris, G. B. Foscolos, A. Kolocouris et al., "Synthesis and antiviral activity evaluation of some aminoadamantane derivatives," Journal of Medicinal Chemistry, vol. 37, no. 18, pp. 2896-2902, 1994.

[38] A. O. Görgülü, K. Koran, F. Özen, S. Tekin, and S. Sandal, "Synthesis, structural characterization and anti-carcinogenic activity of new cyclotriphosphazenes containing dioxybiphenyl and chalcone groups," Journal of Molecular Structure, vol. 1087, pp. 1-10, 2015.

[39] R. A. Kabli, A. A. Khalaf, M. T. Zimaity, A. M. Khalil, A. M. Kaddah, and H. A. Al-Rifaie, "Synthesis of a new series of furyl and thienyl substituted pyrazolines starting with furyl and thienyl chalcones," Journal of the Indian Chemical Society, vol. 68, pp. 47-51, 1991.

[40] B. S. Holla, P. M. Akberali, and M. K. Shivananda, "Studies on arylfuran derivatives: part X. Synthesis and antibacterial properties of arylfuryl- $\Delta^{2}$-pyrazolines," Farmaco, vol. 55, no. 4, pp. 256-263, 2000.

[41] M. Cabrera, M. Simoens, G. Falchi et al., "Synthetic chalcones, flavanones, and flavones as antitumoral agents: biological evaluation and structure-activity relationships," Bioorganic and Medicinal Chemistry, vol. 15, no. 10, pp. 3356-3367, 2007. 

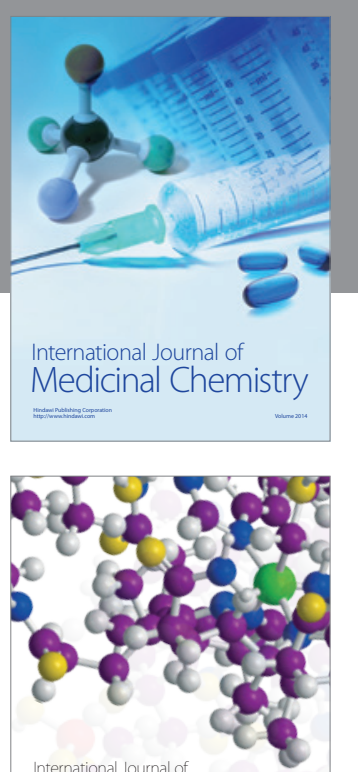

Carbohydrate Chemistry

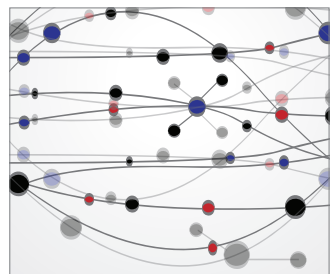

The Scientific World Journal
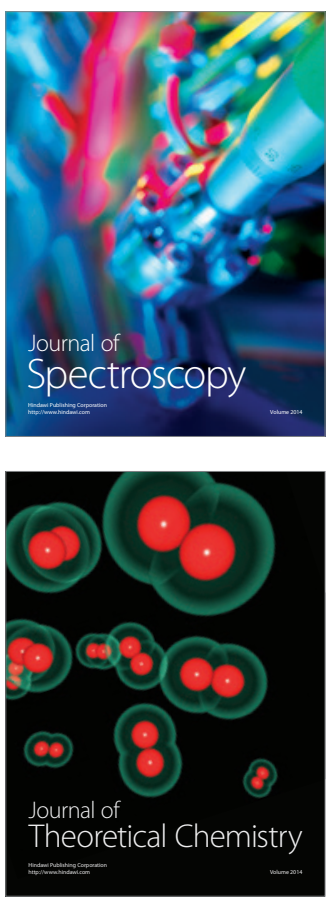
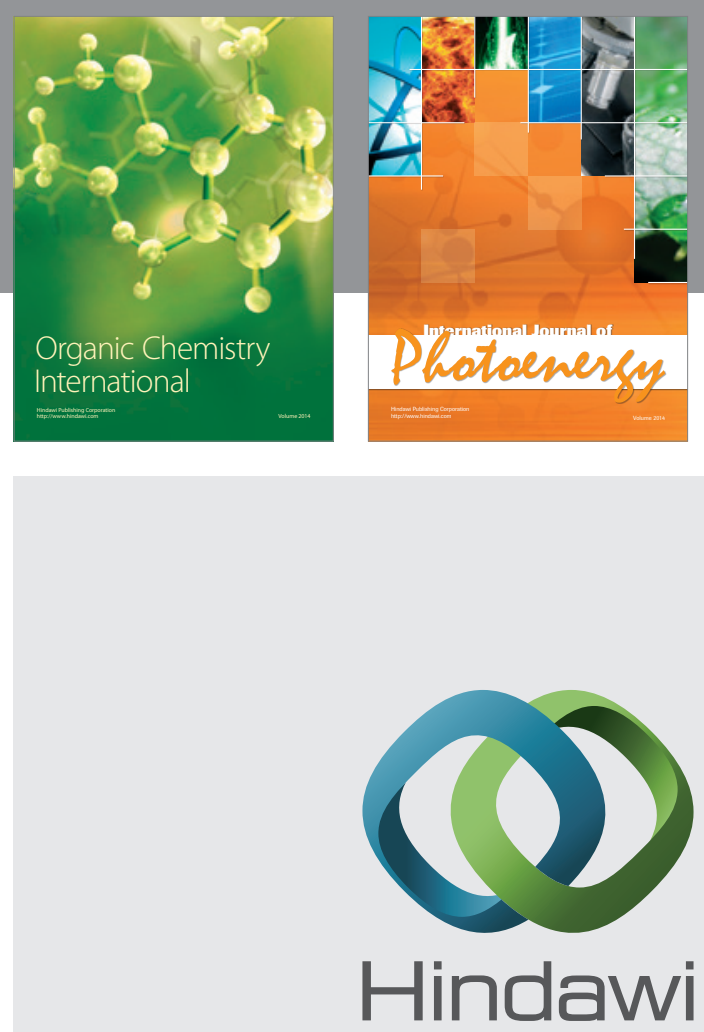

Submit your manuscripts at

http://www.hindawi.com

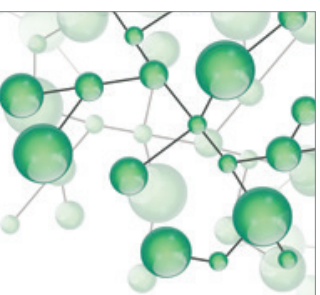

International Journal of

Inorganic Chemistry

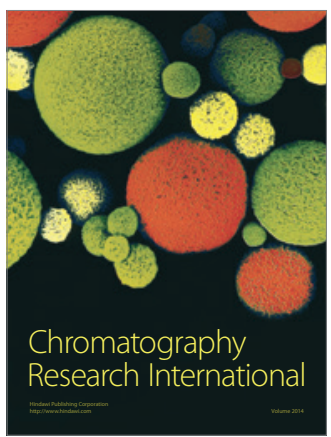

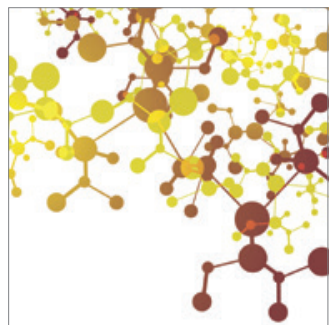

Applied Chemistry
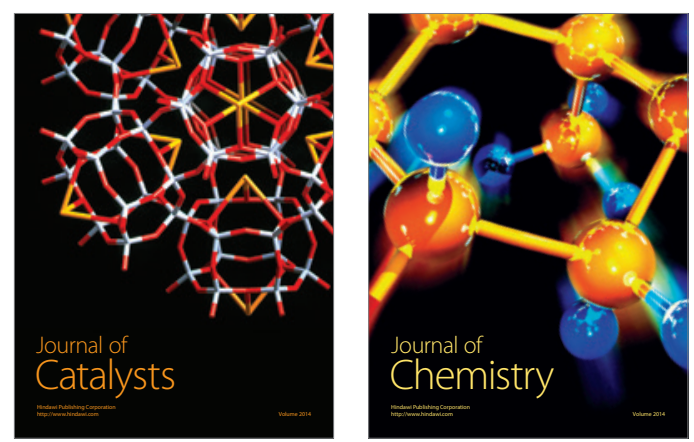
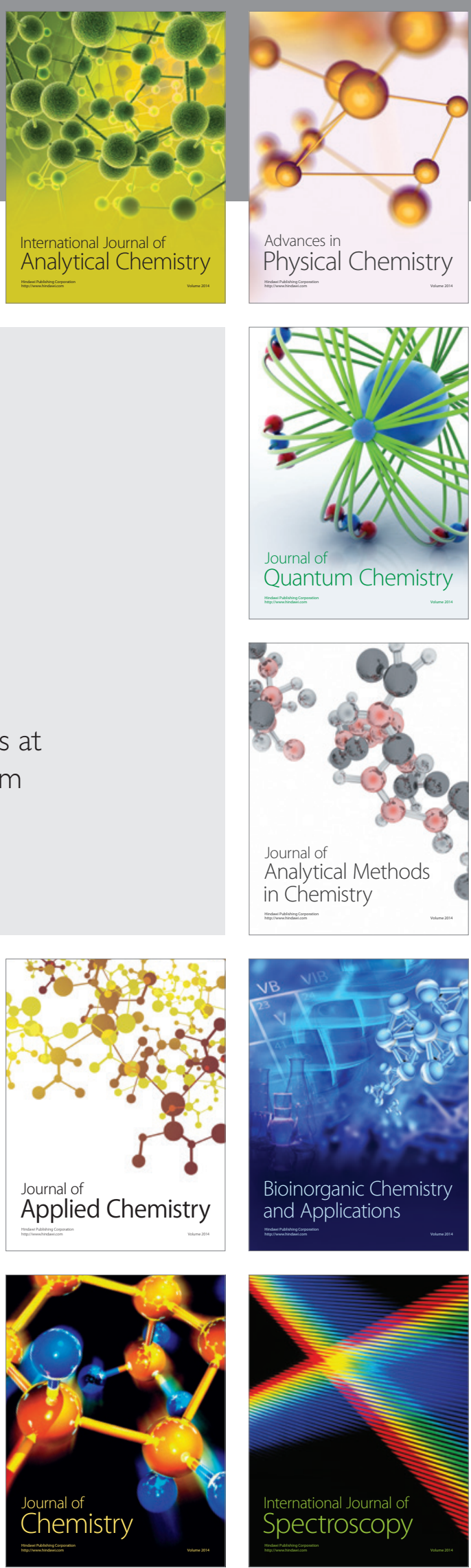